Living the Revolution will be of particular interest to historians of the NEP and the early Stalin era, and it will work well in both undergraduate Soviet history courses and graduate seminars. As suggested at the beginning of this review, historians of housing and consumption in the post-Stalin decades should also read this book to understand how tensions between ideology and everyday life in late socialism were shaped by the earliest attempts to live the Revolution.

STEVEN E. HARRIS

National Air and Space Museum University of Mary Washington

\title{
Socialist Churches: Radical Secularization and the Preservation of the Past in Petrograd and Leningrad, 1918-1988. By Catriona Kelly. DeKalb: Northern Illinois University Press, 2016. xx, 413 pp. Notes. Glossary. Bibliography. Index. Illustrations. Photographs. \$59.00, hard bound.
}

doi: 10.1017/slr.2018.53

Vladislav Mikosha's 1931 film of the demolition of the Church of Christ the Savior in Moscow remains perhaps the most iconic, or iconoclastic, example of the Soviet regime's destructive break with the Russian nation's cultural and religious past. Costly, messy, and needlessly injurious to the already bruised sentiments of Orthodox believers, such sensational reconfigurations of public space and memory were, however, the exception. Catriona Kelly's fascinating new book focuses on the Soviet Union's second city, where urban planners, architects, and museum personnel worked out a less explosive, though resolutely interventionist, approach to managing the religious structures that filled the former imperial capital. Drawing on archival evidence and oral interviews, Kelly shows how church buildings became sites of contestation, as a diverse cast of state and non-state actors debated the meaning of religious architecture in an officially atheist society, what value the prerevolutionary past might possess for the Soviet present, and how public space ought to look, feel, and function in the world's first socialist state.

Party visionaries agreed that the radiant new future they were building had no need (or room) for creaky symbols of superstition inherited from the old regime. Anxious to avoid public disorder yet unwilling to leave religious properties in the possession of Church authorities, the new government legally reclassified churches, cathedrals, chapels, monasteries, and so-called "house churches" as "cultic buildings," declared them part of the "national patrimony," and criminalized their looting or desecration (10). Unique structures deemed to possess exceptional artistic or historical value were placed under the supervisory control of the Museums Department of the People's Commissariat of Enlightenment. In the absence of clear procedural directives from above, and facing chronic problems of underfunding and understaffing on the ground, local planning officials and heritage experts in Petrograd, as elsewhere, lacked the resources and clout to realize their dream of transforming every worthy church into a well-ordered museum. Motivated as much by aesthetics as ideology, these specialists came, ironically, to cultivate a "quasi-religious" commitment to the cause, improvising their own solutions to the problems of preservation (15). While the difference between an exemplary specimen of church architecture that merited preservation and an unremarkable structure that could be safely shuttered or repurposed seemed eminently reasonable to connoisseurs and consultants, such distinctions of taste were maddening and insulting to Orthodox believers, for whom all church buildings were, by definition, sacred liturgical spaces possessed 
of a sacramental significance that transcended their material components and mere provenance.

Throughout the 1920s, disputes concerning the proper meaning and subsequent fate of particular buildings-and of the crosses, chalices, artwork, and iconostases within-resulted in prolonged, often painful, conflicts between rival constituencies and stakeholders from inside and outside the state apparatus. The Stalin Revolution brought with it an escalation of the assault on religious architecture in the name of economic necessity and the reclamation of precious urban space, one that was halted only by the coming of the Second World War. Though the Khrushchev era witnessed a brief revival of antireligious activism, the pendulum would shift toward preservation once more. By the mid-1960s, those select churches still standing in Leningrad had been safely appropriated into a new, dechristianized urban setting and, by the end of the 1980s, recoded as cultural heritage sites and treasured markers of local pride and national identity. As Kelly reminds us, though, the "Petersburg text" is an ever-evolving one (139). Her conclusion peeks forward to the present, as new marketdriven pressures threaten to alter the city's face once again, and with perhaps even more pitiless force than before.

Kelly's interdisciplinary approach complicates and enriches our understanding of Soviet secularization and pushes beyond the familiar narrative of Bolsheviksversus-Believers. The microhistorical lens, applied to the street-level view, destabilizes the image of a monolithic regime imposing godlessness from above, revealing instead a "thickly peopled and often confused territory of fallible individuals reactively making haphazard and contradictory decisions" (263). While the project of spatial secularization was unflinchingly "totalizing" in its ambitions and radical in scope, the decades-long process itself was "non-linear, multi-faceted, and embraced the shifting values and beliefs of secularizers themselves as well as the modifications to religious beliefs and practices" (16). Focusing on the secularization of city space as a process and not simply as a set of outcomes, Kelly invites us to rethink secularization itself, at the most quotidian level, as an ongoing series of negotiations, feints, and improvisations as variegated and muddled as the rich and vibrant way of life its architects sought ultimately to supplant. The comparisons and contrasts Kelly draws with similar, if less overtly ideological, efforts to reconfigure religious space in modern, secularizing societies are instructive, and reflect a widening interest among historians of twentieth-century Russia to situate their subjects in comparative, global perspective. This beautifully written book offers fresh insights throughout. It will be read with great interest and benefit by Russianists from all disciplines.

ROBERT H. GREENE

University of Montana

\footnotetext{
Agents of Terror: Ordinary Men and Extraordinary Violence in Stalin's Secret Police. By Alexander Vatlin. Ed. and Trans. Seth Bernstein. Madison: The University of Wisconsin Press, 2016. xxxiv, 170 pp. Notes. Index. Photographs. $\$ 64.95$, hard bound. doi: $10.1017 /$ slr.2018.54
}

Alexander Vatlin's original and complex work examines the Kuntsevo district NKVD office to reveal how Stalin's Great Terror unfolded on the ground. Located southwest of Moscow, the Kuntsevo district had a population of about 200,000 in 1937. Roughly one thousand people were arrested there during the purges, with the peak of arrests 